\title{
Chemical Studies of Tissue Polypeptide Antigen (TPA). III.* On the Nature of the Antigenic Determinant(s) of TPA Subfraction $\mathbf{B}_{1}$
}

\author{
BO WIKLUND, ${ }^{a}$ BJÖRN LƯNING ${ }^{b, * *}$ and BERTIL BJÖRKLUND ${ }^{a}$
}

${ }^{a}$ Section of Cancer Immunology, National Bacteriological Laboratory, S-105 21 Stockholm, Sweden and

${ }^{b}$ Institute of Organic Chemistry, University of Stockholm, S-106 91 Stockholm, Sweden

Tissue Polypeptide Antigen (TPA)*** which is a protein isolated from e.g. human carcinoma cells, has previously been separated into subfractions and studied with biochemical methods. Gel diffusion studies show that the antigenic determinants are retained through the isolation and purification procedures. Specific modifications of the amino acid residues lysine, tyrosine, trytophan and arginine in subfraction $B_{1}$ have been related to the change in the capacity of the antigen to bind to horse anti-HeLa serum. Complete although reversible loss of binding capacity resulted from blocking of arginine and a minor loss was noted upon modification of tyrosine. No measurable influence was noted upon modification of lysine or tryptophan. No cysteine has been detected in subfraction $B_{1}$. Circular dichroism measurements show that TPA subfraction $B_{1}$ is largely $\alpha$-helical in solution, and that no correlation could be detected between antigenic activity and conformation.

Studies on the biochemical properties of subfractions of tissue polypeptide antigen (TPA) were recently published. ${ }^{1}$ The main subfraction $\mathbf{B}_{1}$, with an apparent $M_{\mathrm{r}}$ of $4.3 \times 10^{4}$, was extensively studied. Sedimentation analysis showed that subfraction $\mathrm{B}_{1}$ in $0.01 \mathrm{M} \mathrm{NaOH}$ appears as a dimer

\footnotetext{
* For Part II in this series, see Ref. 26.

** To whom correspondence should be addressed.

*** Abbreviations used. TPA, tissue polypeptide antigen; PAGE, polyacrylamidegelelectrophoresis; SDS sodium dodecyl sulfate; TPCK, L-1-tosylamido-2phenylethylchloromethylketone; TAME, p-tosyl-Largininemethylester. $\mathrm{HCl}$.
}

with an unusually high frictional ratio, indicating an elongated arrangement of the protein.

Attempts in relating antibody saturation to modification of particular amino acids as well as to changes in secondary and tertiary structure have been published for carcinoembryonic antigen (CEA). ${ }^{2} \mathrm{~A}$ similar approach has been applied in the present investigation on tissue polypeptide antigen (TPA). Since only part of the primary structure of subfraction $B_{1}$ is known, attempts were made to induce quantitative modification in order to reveal if certain amino acids per se participate in any antigenically important sites.

Circular dichroism measurements were made to elucidate whether any gross conformational changes accompanied the chemically induced changes of the antigen-antibody reaction.

\section{MATERIALS AND METHODS}

All chemicals used were of analytical grade or better. Ultraviolet spectra were measured with a Beckman DB-G spectrophotometer, fluorescence was measured with an Aminco Bowman spectrofluorometer, model 4-8106, and the intensity of the emitted light given in arbitrary units. CD was measured with a Jasco Model J 41 A spectropolarimeter.

Antigen. Tissue polypeptide antigen was obtained from a pool of at least 30 different human carcinoma tumors of different sites and types and purified as described elsewhere. ${ }^{3,4,1}$ In principle the homogenized tumor tissue after defatting with ether and removal of soluble proteins (Washed Tissue 
Powder, WTP) is extracted at $\mathrm{pH} 9.5$ with water. The extract, adjusted to $\mathrm{pH} 7.5$, is heated to $90^{\circ} \mathrm{C}$ and then passed through a column of Biogel A-50 m. The protein mid fraction $\left(M_{\mathrm{r}} 15 \times 10^{6}\right)$ is precipitated at $\mathrm{pH} 5$ and the precipitate eluted with a downward $\mathrm{pH}$ gradient in a Sephadex G 15 column. ${ }^{4}$ The fraction eluted between pH 4.5 and 3, containing $2 \%$ of the protein and $20-50 \%$ of the antigenic activity, was collected and denoted TPA. This TPA was separated in the presence of SDS on Sephadex G 200 into four fractions, designated $A, B_{1}, B_{2}$ and $C$. The latter three fractions gave the same slope ratio and minimum diameter in the hemagglutination inhibition test (see below).

In this investigation subfraction $B_{1}$ with an apparent $M_{\mathrm{r}}$ of $4.3 \times 10^{4}$ was used. This material has a specific TPA activity (see below) of $3-5$ units per $\mu \mathrm{g}(\mathrm{U} / \mu \mathrm{g})$. In a few experiments subfraction $\mathrm{C}$ with a specitic activity of $2-3 \mathrm{U} / \mu \mathrm{g}$ was used.

Immune serum. Horse anti-HeLa serum was prepared by i.v. injections over 7 months of $1 \mathrm{~g}$ of insoluble residue of HeLa cells. ${ }^{5}$ After 15 months 4 i.m. injections of $40 \mathrm{mg}$ of the same antigen in Freunds adjuvant were given biweekly and one bleeding (Nov. 26, 1962) was used throughout.

The horse serum was absorbed with sheep red cells, then with $40 \mathrm{mg}$ lyophilized human plasma that had previously been absorbed with sheep red cells. After removal of precipitates the serum was passed through a Biogel A- $0.5 \mathrm{~m}$ column. The antibody, agglutinating sheep red cells tanned and labeled with TPA, was recovered in the IgG fraction.

Rabbit anti-subfraction $B_{1}$ serum was prepared by three i.m. injections once a month. The first inoculate consisted of $130 \mu \mathrm{g}$ subfraction $\mathrm{B}_{1}$ in complete Freunds adjuvant and the following of 65 $\mu \mathrm{g}$ subfraction $\mathrm{B}_{1}$ in incomplete Freunds adjuvant. Immune serum was prepared from a bleeding 12 days after the third inoculation.

Characterization of antigen and antibody by double immunodiffusion. Agarose gel (Biorad), $1 \%$ in phosphate buffered saline with $0.01 \%$ thimerosal (Elanco) $\mathrm{pH} 7.5$, was layered on plastic plates $(8 \times 9$ $\mathrm{cm}$, LKB Multiphor). Antigens used: HeLa cells ( 3 $\times 10^{7}$ cells $)$ and homogenized tissues $(0.37 \mathrm{~g}$ wet weight of liver met. from four individuals) * were washed five times in $1 \mathrm{ml}$ distilled water and then extracted with $1 \mathrm{ml}$ of $0.15 \mathrm{M} \mathrm{NaOH}$ each at $20^{\circ} \mathrm{C}$ for one hour. After centrifugation $\left(5000 \times g\right.$ at $5^{\circ} \mathrm{C}$ for $20 \mathrm{~min}$ ) the supernatants were collected, and $\mathrm{pH}$ adjusted to 7.5. WTP extract, before and after heat treatment, Biogel A-50m column inlay, TPA (after $\mathrm{pH}$ gradient elution) and TPA subfraction $\mathrm{B}_{1}, \mathrm{~B}_{2}$ and $\mathrm{C}$ (SDS removed) ${ }^{1}$ were also used.

Double diffusion patterns (Figs. 1a and 1b) against horse anti-HeLa serum (absorbed with $40 \mathrm{mg}$ human plasma per $\mathrm{ml}$ serum) show a major precipitin line of identity through the tumor- and

* Liver metastases originating from the following primary carcinomas: mamma and ventricle, mamma, ventricle, and intestine.
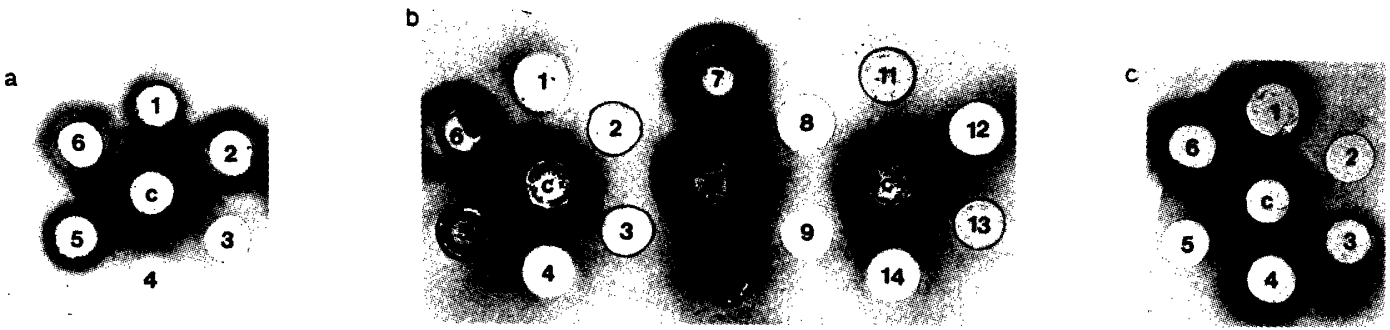

Fig. 1. Double diffusion analysis of TPA" preparations. (a). Central well: $40 \mu \mathrm{l}$ of horse anti-HeLa serum; well 1 and 5: $20 \mu \mathrm{l}$ of tumor extract (from $0.37 \mathrm{~g}$ wet tumors $/ \mathrm{ml}) ; 2: 20 \mu \mathrm{l}$ of HeLa cell extract $\left(3 \times 10^{7}\right.$ cells $\left./ \mathrm{ml}\right) ; 3: 20$ $\mu \mathrm{l}$ of subfraction $\mathrm{B}_{1}(1.2 \mathrm{mg} / \mathrm{ml}) ; 4: 20 \mu \mathrm{l}$ of WTP extract, Biogel A-50m inlay $(10 \mathrm{mg} / \mathrm{ml}) ; 6: 10 \mu \mathrm{l}$ of normal human serum. (b). Central wells: $60 \mu \mathrm{l}$ of horse anti-HeLa serum, absorbed with lyophilized human plasma (40 $\mathrm{mg} / \mathrm{ml}$ ) from several individuals; wells 1 and $4: 8 \mu \mathrm{l}$ of normal human serum; 2,3,11 and 13:60 $\mu \mathrm{l}$ of subfraction $\mathrm{B}_{1}(1 \mathrm{mg} / \mathrm{ml}) ; 5$ and 10: $60 \mu \mathrm{l}$ of WTP extract, not heat treated $(10 \mathrm{mg} / \mathrm{ml}) ; 6$ and 7: $60 \mu \mathrm{l}$ of WTP extract, heat treated $(10 \mathrm{mg} / \mathrm{ml}) ; 8$ and 9: $60 \mu \mathrm{l}$ of WTP extract, Biogel A-50m inlay $(10 \mathrm{mg} / \mathrm{ml}) ; 12$ and 14:60 $\mu \mathrm{l}$ of TPA (after $\mathrm{pH}$ gradient elution) $(1.3 \mathrm{mg} / \mathrm{ml})$. (c). Central well: $40 \mu \mathrm{l}$ of rabbit anti-subfraction $\mathrm{B}_{1}$ serum; well 1: $60 \mu \mathrm{l}$ of subfraction $B_{1}(1.2 \mathrm{mg} / \mathrm{ml}) ; 2: 60 \mu$ of subfraction $B_{2}(1.6 \mathrm{mg} / \mathrm{ml}) ; 3: 60 \mu l$ of subfraction $C(1.6 \mathrm{mg} / \mathrm{ml}) ; 4$ and 6 : $10 \mu \mathrm{l}$ of normal human serum. 


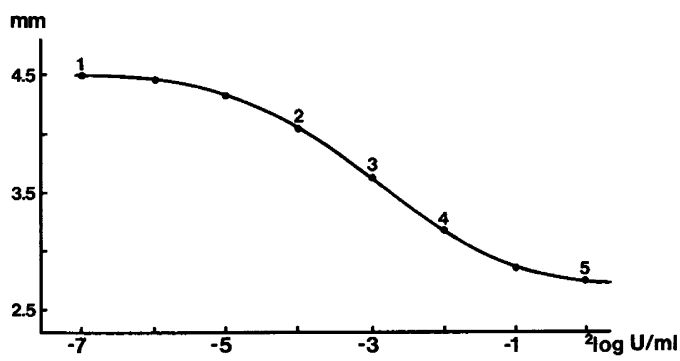

Fig. 2. Standard curve in hemagglutination inhibition test, diameter versus ${ }^{2} \log \mathrm{U} / \mathrm{ml}$. Point 1 represents the max. diameter obtained at no inhibition of the antibody; points 2,3 and 4 are situated at the linear part of the curve, used for determination of the activity; point 5 shows the level of complete specific inhibition.

HeLa-extracts, WTP-extracts, TPA and subfraction $B_{1}$. The heat treatment of the WTP extract does not alter the precipitin line. The tumor- and HeLaextracts show precipitin lines that are not related to purified TPA. None of the precipitin lines shown by TPA active materials crossreact with normal human serum. Rabbit anti-subfraction $B_{1}$ serum gives one precipitin line of identity between subfractions $B_{1}$, $\mathrm{B}_{2}$ and $\mathrm{C}$ (Fig. 1c).

The occasionally appearing double lines between purified TPA preparations and anti-HeLa serum could be assigned to aggregation of TPA molecules rather than to the presence of other antigens capable of precipitating anti-HeLa serum.

Determination of antigenic activity. The TPAactivity was estimated in a heterologous system by means of a standardized hemagglutination inhibition test, ${ }^{3,6}$ labeling antigen: TPA obtained by $\mathrm{pH}$ gradient elution, antiserum: horse anti-HeLa serum treated as described above. The test was performed on two-step dilutions of the samples in micro titration plates (Linbro IS-MRC-96) with spherical bottoms. The diameters of the hemagglutination patterns for the series of dilutions of each sample were plotted against ${ }^{2} \log c_{\text {antigen }}$ (Fig. 2 ), expressed in $\mathrm{U} / \mathrm{ml}$. Using the definition of a hemagglutination unit (U) given by Björklund ${ }^{3}$ the point of $50 \%$ inhibition is found to correspond to a concentration of $1 / 8$ unit TPA per $\mathrm{ml}$. The slope of the steepest part of the curve was assumed to be dependent on the affinity between antigen and antibody. Incomplete inhibition manifested by a higher minimum diameter of the hemagglutination pattern may reflect the lack of certain determinants in the antigen tested in relation to the antigen used as labeling antigen. The ratio between the slope for a sample and that of standard TPA in the same experiment was always determined. In intra- and interassay reproducibility determined by repeated testing of a solution of purified antigen is $\pm 10 \%$ of the value.

Amino acid analysis. $\mathrm{HCl}$ hydrolysates were analyzed with the aid of an automatic amino acid analyzer (Jeol, JLC-6AH), using a $30 \mathrm{~cm}$ column of Durrum DC-6A and the Durrum Pico Buffer System II (both from Pierce, Rockford, Ill.). The buffers were supplied to the column through an ammonia filtration system. Hydrolysis of subfraction $B_{1}$ modified by 1,2-cyclohexanedione was performed in the presence of mercaptoacetic acid. ${ }^{7}$

p-Toluenesulfonic acid hydrolysis. ${ }^{8}$ Subfraction $\mathrm{B}_{1}$ was hydrolyzed for $18 \mathrm{~h}$ at $110^{\circ} \mathrm{C}$ with $3 \mathrm{M}$ ptoluenesulphonic acid in presence of $0.2 \%$ tryptamine in evacuated ampoules.

Electrophoresis in polyacrylamide gel. Gels were 4.5 $\times 110 \mathrm{~mm}$. Running gel: $7 \%, 0.1 \%$ crosslink, $0.75 \mathrm{M}$ Tris- $\mathrm{HCl}$, pH 8.6. Stacking gel: $2.5 \%, 0.63 \%$ crosslink, $0.12 \mathrm{M}$ Tris- $\mathrm{HCl}, \mathrm{pH} 6.8$. Inlay: $30 \mu \mathrm{g}$ protein in $25 \mu \mathrm{l}$ of $0.01 \mathrm{M} \mathrm{NH}_{4} \mathrm{HCO}_{3}, 8 \mathrm{M}$ urea. Bromophenol Blue (BFB) was used as inner reference, staining with Coomassie Blue. For determination of TPA activity gels were cut into slices 1.3 and $5 \mathrm{~mm}$ thick, which were extracted with 0.3 and $1.0 \mathrm{ml} 0.1 \mathrm{M} \mathrm{NH}_{4} \mathrm{HCO}_{3}$, respectively.

Reaction of TPA with anhydrides of succinic, maleic and citraconic acid. ${ }^{9,10,11}$ Subfraction $\mathrm{B}_{1}$ and $\mathrm{C}(0.2$ $-1.0 \mathrm{mg}$ ) were dissolved in $1 \mathrm{ml}$ each of $1 \mathrm{M}$ sodium bicarbonate, $8 \mathrm{M}$ urea and the $\mathrm{pH}$ adjusted to 9.0 $(\mathrm{NaOH})$. Eight $25 \mu \mathrm{l}$ portions of a $25 \%$ anhydride (succinic, maleic or citraconic) solution in acetone were added under vigorous stirring over $10 \mathrm{~min}$, keeping $\mathrm{pH}$ above 8.8. The reaction mixture was desalted with Sephadex G 25 (Pharmacia, Uppsala) in $0.1 \mathrm{M} \mathrm{NH}_{4} \mathrm{HCO}_{3}$ and lyophilized. Subfractions $\mathrm{B}_{1}$ and $\mathrm{C}$, treated with $1 \% \mathrm{SDS}$ in $0.1 \mathrm{M} \mathrm{NH}_{4} \mathrm{HCO}_{3}$ for $15 \mathrm{~min}$ at $100{ }^{\circ} \mathrm{C}$, were acylated in the same way as described above.

De-acylation of citraconyl TPA. ${ }^{11}$ Subfraction $\mathrm{B}_{1}$ $(100 \mu \mathrm{g})$ citraconylated in the presence of SDS was incubated at $20^{\circ} \mathrm{C}$ for $2 \mathrm{~h}$ in $10 \mathrm{M}$ urea, $\mathrm{pH} 2.5(\mathrm{HCl})$, neutralized with solid $\mathrm{NH}_{4} \mathrm{HCO}_{3}$ and desalted with Sephadex G 25 in $0.1 \mathrm{M} \mathrm{NH}_{4} \mathrm{HCO}_{3}$.

Dansylation. $^{12}$ Subfraction $\mathrm{B}_{1}(40 \mu \mathrm{g})$ was

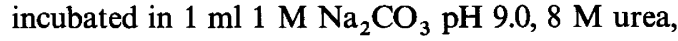
mixed with $200 \mu \mathrm{l}$ of $10 \%$ dansyl chloride in acetone, 
at $20^{\circ} \mathrm{C}$ for $1 \mathrm{~h}$ and $4{ }^{\circ} \mathrm{C}$ for another $18 \mathrm{~h}$, and desalted with Sephadex G 25 in $0.1 \mathrm{M} \mathrm{NH}_{4} \mathrm{HCO}_{3}$.

Acylation of subfraction $B_{1}$ with $\mathrm{N}$-succinimidyl3[4-hydroxy-5( $\left.{ }^{125} I\right)$-iodophenyl] propionate $(B H R) .{ }^{13}$ Subfraction $\mathrm{B}_{1}(200 \mu \mathrm{g}, 4 \mathrm{nmol})$ was dissolved in $100 \mu 10.01 \mathrm{M} \mathrm{NaOH}$. After the addition of $2 \mathrm{mg} \mathrm{NaHCO}$, the solution was transferred to a glass tube in which $1 \mathrm{mCi}(0.5 \mathrm{nmol})$ of BHR had been distributed in a thin layer by evaporation of a benzene solution. The tube was stoppered and shaken gently for $25 \mathrm{~min}$ at $0{ }^{\circ} \mathrm{C}$. After the addition of $3 \mathrm{mg}$ glycine the reaction mixture was desalted in $0.2 \mathrm{M} \mathrm{NH}_{4} \mathrm{HCO}_{3}$ with Sephadex G 25 .

Nitration. ${ }^{14}$ Subfraction $\mathrm{B}_{1}(35 \mu \mathrm{g})$ in $0.5 \mathrm{ml} 0.1 \mathrm{M}$ $\mathrm{NaHCO}_{3} 8 \mathrm{M}$ urea pH 8.4 was incubated with $25 \mu \mathrm{l}$ of a $16 \%$ solution of tetranitromethane in ethanol for $85 \mathrm{~min}$ at $20^{\circ} \mathrm{C}$, and then desalted with Sephadex G 25 in $0.1 \mathrm{M} \mathrm{NH}_{4} \mathrm{HCO}_{3}$.

Iodination with $\mathrm{KI}_{3} \cdot{ }^{15,16}$ Freshly prepared $\mathrm{KI}_{3}$ solutions $(2.0,0.2,0.02,0.002$ and $0 \mathrm{mM}$ in $0.1 \mathrm{M}$ $\mathrm{Na}_{2} \mathrm{CO}_{3} \mathrm{pH}$ 9.2) were rapidly mixed with equal portions $(50 \mu \mathrm{l})$ of a solution containing subfraction $\mathrm{B}_{1}\left(15 \mu \mathrm{g}\right.$ in $0.1 \mathrm{M} \mathrm{Na}_{2} \mathrm{CO}_{3} \mathrm{pH}$ 9.2). The mixtures were incubated for $1 \mathrm{~h}$ at $20^{\circ} \mathrm{C}$ and were then immediately diluted in $1 \%$ human serum solution and tested for TPA activity.

Iodination with ${ }^{125} I$ in presence of chloramine-T. ${ }^{17}$ The antigen $(90 \mu \mathrm{g})$ was dissolved in $100 \mu \mathrm{l} 0.02 \mathrm{M}$ $\mathrm{NaOH}$ followed by the addition of $2 \mathrm{mg} \mathrm{NaHCO}$. This solution was divided into three aliquots, the $\mathrm{pH}$ values of which were adjusted to 7.4, 7.7 and 8.5, respectively. These solutions were radioiodinated by a standard method ${ }^{17}$ using sequential addition of reagents. TPA was exposed to the oxidizing conditions for only $15 \mathrm{sec}$. The iodinated protein was desaltedin $0.2 \mathrm{M} \mathrm{NH}_{4} \mathrm{HCO}_{3}$ with Sephadex $\mathrm{G}$ 25 within 5 min from the start of the reaction.

Reaction of subfraction $B_{1}$ with dimethyl-(2hydroxy-5-nitrobenzyl)sulfonium bromide. ${ }^{18}$ Subfraction $\mathrm{B}_{1}(750 \mu \mathrm{g})$ and human serum albumin
(HSA) $(300 \mu \mathrm{g})$ were dissolved in $1 \mathrm{ml}$ portions of 0.1 $\mathrm{M} \mathrm{HCOOH} 8 \mathrm{M}$ urea $\mathrm{pH}$ 3.5. To each protein solution, $10 \mathrm{mg}$ of the alkylating reagent was added and reaction was allowed to proceed for $3 \mathrm{~h}$ at $20^{\circ} \mathrm{C}$. The alkylated proteins were immediately desalted with Sephadex G $25(2.5 \times 35 \mathrm{~cm})$ in $0.1 \mathrm{M} \mathrm{HCOOH}$ and lyophilized.

BrCN-cleavage. ${ }^{19}$ Aliquots of subfraction $\mathrm{B}_{1}$ and alkylated subfraction $\mathbf{B}_{1}(300 \mu \mathrm{g})$ were dissolved in $0.5 \mathrm{ml}$ portions of $70 \% \mathrm{HCOOH}$, solid $\mathrm{BrCN}(5 \mathrm{mg})$ was added and the solutions incubated for $24 \mathrm{~h}$ at $20^{\circ} \mathrm{C}$. After lyophilization they were filtered through Sephadex G 75 in $0.1 \mathrm{M} \mathrm{HCOOH}$.

Reaction with diazomethane. ${ }^{20}$ To a solution of 75 $\mu \mathrm{g}$ of subfraction $\mathrm{B}_{1}$ in $2 \mathrm{ml}$ of $0.03 \mathrm{M} \mathrm{HCl}$ in $85 \%$ ethanol, $800 \mu \mathrm{l} 3 \%$ solution of diazomethane in ether was added and the mixture kept for $4 \mathrm{~h}$ at $-2{ }^{\circ} \mathrm{C}$. The $\mathrm{pH}$ rose from 1.97 to 2.15 . The solution was evaporated to $0.2 \mathrm{ml}$ and diluted with $0.5 \mathrm{ml} 0.1$ M $\mathrm{HCOOH}, 8 \mathrm{M}$ urea prior to activity measurement.

Transformation of arginine residues in subfraction $B_{1}$ to $\mathrm{N}^{5}$-(4-oxo-1,3-diaspiro[4.4]non-2-ylidene)-Lornithine ${ }^{21}$ (CHD-subfraction $\left.B_{1}\right)$. To a solution of 50 $\mu \mathrm{g}$ subfraction $\mathrm{B}_{1}$ in $0.5 \mathrm{ml} 0.2 \mathrm{M} \mathrm{NaOH}, 10 \mathrm{mg}$ of 1,2-cyclohexanedione was added and the mixture kept for $3 \mathrm{~h}$ at $20^{\circ} \mathrm{C}$, pH was adjusted to 8.4 $\left(\mathrm{NaHCO}_{3}\right)$ and the modified protein desalted with Sephadex G 25 in $0.1 \mathrm{M} \mathrm{NH}_{4} \mathrm{HCO}_{3}$.

Transformation of arginine residues in subfraction $B_{1}$ to $\quad \mathrm{N}^{7}, \mathrm{~N}^{8}-(1,2-$ dihydroxycyclohex-1,2-ylene $)-\mathrm{L}-$ arginine ${ }^{7}$ ( $D H C H$-subfraction $B_{1}$ ). Four aliquots of subfraction $B_{1}(400 \mu \mathrm{g})$ were dissolved in $1.0 \mathrm{ml} 0.25$ $\mathrm{M}$ borate buffer $\mathrm{pH}$ 9.0. To these solutions, 1,2cyclohexanedione in $2.0 \mathrm{ml}$ portions of $0.25 \mathrm{M}$ borate buffer $\mathrm{pH} 9.0$ was added to give molar ratios between reagent and arginine residues, ranging from 40 to 4000 . The reaction mixtures were incubated for $2 \mathrm{~h}$ at $36^{\circ} \mathrm{C}$ and desalted with Sephadex G 25 in $0.2 \mathrm{M} \mathrm{NH}_{4} \mathrm{HCO}_{3}$.

Table 1. De-blocking of $\mathrm{DHCH}$-subfraction $\mathrm{B}_{1}$ at $36^{\circ} \mathrm{C}$.

\begin{tabular}{lclll}
\hline $\begin{array}{l}\text { Composition of } \\
\text { deblocking solution } \\
\text { in } 8 \mathrm{M} \text { urea }\end{array}$ & $\begin{array}{l}\text { Reaction } \\
\text { time } \\
(\mathrm{h})\end{array}$ & $\begin{array}{l}\text { Per cent } \\
\text { restored } \\
\text { arginine }\end{array}$ & $\begin{array}{l}\text { Per cent } \\
\text { restored } \\
\text { TPA-activity }\end{array}$ & $\begin{array}{l}\text { Slope } \\
\text { ratio }\end{array}$ \\
\hline $0.05 \mathrm{M} \mathrm{NH}_{2} \mathrm{OH}$ in $0.2 \mathrm{M} \mathrm{NH}_{4} \mathrm{HCO}_{3}$ & 2 & 51 & 26 & 1.00 \\
$0.50 \mathrm{M} \mathrm{NH} \mathrm{OH}_{2} \mathrm{On} 0.2 \mathrm{M} \mathrm{NH}_{4} \mathrm{HCO}_{3}$ & 2 & 56 & 41 & 1.00 \\
$\begin{array}{l}0.37 \mathrm{M} \mathrm{NH} \mathrm{NH}_{2} \mathrm{OH} \text { in } 0.1 \mathrm{M} \mathrm{NaHCO}_{3} \\
7 \% \mathrm{HS}\left(\mathrm{CH}_{2}\right)_{2} \mathrm{OH}\end{array}$ & 16 & 77 & 50 & 1.00 \\
\hline
\end{tabular}


Table 2. Activity and slope ratio of acylated TPA subfractions.

\begin{tabular}{|c|c|c|c|c|}
\hline Subfraction & Acyl & $\begin{array}{r}\text { Specific } \\
\text { activity } \\
\% \\
\end{array}$ & Yield $^{a}$ & $\begin{array}{l}\text { Slope ratio } \\
\text { in activity } \\
\text { measurement }\end{array}$ \\
\hline $\begin{array}{l}\text { SDS treated } \\
\text { Subfraction } \mathrm{B}_{1}\end{array}$ & $\begin{array}{l}- \\
\text { Succinyl } \\
\text { Maleyl } \\
\text { Citraconyl }\end{array}$ & $\begin{array}{rr}3.1 & 100 \\
2.7 & 87 \\
2.6 & 84 \\
2.7 & 87\end{array}$ & $\begin{array}{c}100^{b} \\
62 \\
59 \\
62\end{array}$ & $\begin{array}{l}1.00 \\
1.00 \\
1.00 \\
1.00\end{array}$ \\
\hline Subfraction $\mathbf{B}_{1}$ & $\begin{array}{l}- \\
\text { Succinyl } \\
\text { Citraconyl }\end{array}$ & $\begin{array}{l}3.1 \\
\text { n.d. } \\
\text { n.d. }\end{array}$ & $\begin{array}{c}100^{b} \\
53 \\
53\end{array}$ & $\begin{array}{l}1.00 \\
1.00 \\
1.00\end{array}$ \\
\hline $\begin{array}{l}\text { SDS treated } \\
\text { Subfraction C }\end{array}$ & $\begin{array}{l}- \\
\text { Succinyl } \\
\text { Citraconyl }\end{array}$ & $\begin{array}{l}2.5 \\
\text { n.d. } \\
\text { n.d. }\end{array}$ & $\begin{array}{c}100^{b} \\
59 \\
59\end{array}$ & $\begin{array}{l}1.00 \\
0.93 \\
0.93\end{array}$ \\
\hline Subfraction C & $\begin{array}{l}- \\
\text { Succinyl } \\
\text { Citraconyl }\end{array}$ & $\begin{array}{l}2.5 \\
\text { n.d. } \\
\text { n.d. }\end{array}$ & $\begin{array}{c}100^{b} \\
42 \\
33\end{array}$ & $\begin{array}{l}1.00 \\
1.00 \\
1.00\end{array}$ \\
\hline
\end{tabular}

${ }^{a} \%$ TPA activity after acylation. ${ }^{b}$ By definition.

De-blocking of $\quad$ DHCH-subfraction $\quad B_{1}$ with hydroxylamine. ${ }^{7}$ Aliquots of subfraction $\mathrm{B}_{1}(300 \mu \mathrm{g})$ were reacted to form $\mathrm{DHCH}$-subfraction $\mathrm{B}_{1}(88 \%$ modification) as described above. The lyophilized completely inactive portions of $\mathrm{DHCH}$-subfraction $\mathrm{B}_{1}$ were dissolved in $0.5 \mathrm{ml}$ portions of three different de-blocking solutions listed in Table 1, incubated at $36^{\circ} \mathrm{C}$ and desalted with Sephadex G 25 in $0.2 \mathrm{M} \mathrm{NH}_{4} \mathrm{HCO}_{3}$.

Trypsine cleavage of $\mathrm{DHCH}$-subfraction $\mathrm{B}_{1}$. Aliquots $(1.5 \mathrm{mg})$ of subfraction $\mathrm{B}_{1}$ and $\mathrm{DHCH}$ - subfraction $\mathrm{B}_{1}$ were dissolved in $3.5 \mathrm{ml}$ each of $0.1 \mathrm{M}$ $\mathrm{NaHCO}_{3}$ with $0.01 \mathrm{M} \mathrm{CaCl}_{2}, \mathrm{pH}$ 8.4. To each of the TPA preparations, $100 \mu \mathrm{l}$ of TPCK-trypsine solution $(0.6 \mathrm{mg} / \mathrm{ml}, 107 \mathrm{IU}$ TAME$/ \mathrm{mg})$ was added and the mixtures were incubated for $1 \mathrm{~h}$ at $35^{\circ} \mathrm{C}$. Urea $(1.8 \mathrm{~g})$, mercaptoethanol $(300 \mu \mathrm{l})$ and hydroxylammonium chloride $(63 \mathrm{mg})$ were added successively, followed by an incubation for $16 \mathrm{~h}$ at $37^{\circ} \mathrm{C}$.

Table 3. Mobility in PAGE of acylated TPA-preparations.

\begin{tabular}{|c|c|c|c|c|c|c|c|}
\hline BAND & $\begin{array}{l}\text { Succinyl } \\
\mathbf{B}_{1}\end{array}$ & $\begin{array}{l}\text { Citraconyl } \\
\mathbf{B}_{1}\end{array}$ & $\begin{array}{l}\text { SDS } \\
\text { Succinyl } \\
\text { B }_{1}\end{array}$ & $\begin{array}{l}\text { SDS } \\
\text { Citraconyl } \\
\mathrm{B}_{1}\end{array}$ & $\begin{array}{l}\text { Succinyl } \\
\text { C }\end{array}$ & $\begin{array}{l}\text { Citraconyl } \\
\text { C }\end{array}$ & $\begin{array}{l}\text { SDS- } \\
\text { Citraconyl } \\
\text { C }\end{array}$ \\
\hline I & 0.26 & 0.26 & - & - & - & - & - \\
\hline II & 0.44 & 0.44 & 0.47 & 0.47 & - & - & - \\
\hline III & 0.47 & 0.47 & 0.49 & 0.49 & - & - & - \\
\hline IV & 0.49 & 0.49 & 0.52 & 0.52 & - & - & - \\
\hline V & 0.52 & 0.52 & 0.57 & 0.57 & - & - & - \\
\hline VI & 0.58 & 0.58 & 0.60 & 0.60 & - & - & - \\
\hline VII & 0.62 & 0.62 & & & - & - & - \\
\hline VIII & 0.67 & 0.67 & & & - & - & - \\
\hline IX & - & - & - & - & - & - & 0.98 \\
\hline $\mathrm{X}$ & - & - & 1.0 & 1.0 & 1.0 & 1.0 & - \\
\hline
\end{tabular}




\section{RESULTS}

Modification of subfraction $B_{1}$ by acylation methods

Subfraction $B_{1}$ was acylated with succinic, maleic and citraconic anhydride. An approximate quantitation of the amount of maleylation and citraconylation was obtained by measuring the absorbance at $218 \mathrm{~nm}$, subtracting that of the intact protein and using the absorbance of the corresponding acid as a reference. The protein, at this wavelength, has a low absorbance in comparison with the conjugated chromophores of the modifying groups. The absorbance of the derivatives does not differ markedly from that of the free acids. Portions of $100 \mu \mathrm{g}$ subfraction $\mathrm{B}_{1}$, containing approximately $60 \mathrm{nmol}$ lysine, were acylated with maleic and citraconic anhydride yielding in both cases an incorporation of around 80 nmol acyl group. Assuming a quantitative acylation of the amino groups, hydroxyl groups were also acylated. ${ }^{22}$ The TPA activity was largely retained as is evident from Table 2. The slope ratios and the minimum diameters were not changed. Electrophoresis of acylated subfraction $\mathbf{B}_{1}$ was performed at $\mathrm{pH} 8.6$ and the result is presented in Table 3. The distribution of TPA activity over several bands can be explained in view of the differential acylation of hydroxyl groups producing proteins with variation in charge. ${ }^{22}$ Upon deacylation of citraconylated subfraction $B_{1}, a 60 \%$ yield of active antigen was separated from the citraconate ions.

After dansylation of subfraction $B_{1}$, the amino acid analysis showed a quantitative yield of protein in which the mol- $\%$ of lysine had decreased from 6.8 to 3.6 and that of tyrosine from 2.5 to $0.5 \mathrm{~mol} \%$. Polyamide thin layer chromatography of acid hydrolysates $^{23}$ of dansylated subfraction $\mathbf{B}_{1}$
Table 4. Iodination of TPA in alkaline medium.

\begin{tabular}{rll}
$\begin{array}{l}\text { Molar ratio } \\
\text { I } 2 \text { /Tyrosines } \\
\text { in TPA }\end{array}$ & $\begin{array}{l}\text { Yield }^{a} \\
\text { of } \\
\text { TPA-activity }\end{array}$ & $\begin{array}{l}\text { Slope } \\
\text { ratio }\end{array}$ \\
\hline 1000 & 17 & 0.83 \\
100 & 54 & 1.00 \\
10 & 84 & 1.17 \\
1 & 109 & 1.07 \\
0 & 100 & 1.00 \\
\hline
\end{tabular}

${ }^{a}$ In $\%$ of starting material.

showed massive spots of $\varepsilon$-dansylated lysine and $O$ dansylated tyrosine, without however, giving any evidence for an $N$-terminal amino acid. TPA activity of the dansylated protein was less than $3 \%$.

Subfraction $B_{1}$, acylated by Bolton-Hunter technique, contained $70 \%$ of the original TPA activity and a radioactivity of $50-85 \mathrm{kBq}$ per $\mu \mathrm{g}$. The labeled antigen showed a complete inhibition and the same slope ratio as standard TPA in the TPA activity test. The labeled antigen has been used in the development of a radioimmunoassay technique for the determination of TPA activity in various solutions (e.g. human serum). ${ }^{24,25}$ In that assay, radioiodinated TPA shows a maximum binding capacity of approximately $65 \%(\mathrm{~B} / \mathrm{T})$ in the presence of excess antibody.

\section{Nitration}

After reaction of subfraction $B_{1}$ with tetranitromethane, the amino acid analysis showed a quantitative yield of nitrated antigen in which tyrosine alone could no longer be detected. The fluorescence (activation $288 \mathrm{~nm}$, emission $350 \mathrm{~nm}$ ) of subfraction $\mathrm{B}_{1}$ decreased to $3 \%$ after nitration and $40 \%$ of the TPA activity was retained. Subfraction

Table 5. Results of iodination of TPA in the presence of chloramine-T.

\begin{tabular}{lllll}
\hline & \multicolumn{2}{l}{ Data of ${ }^{125} \mathrm{I}-\mathrm{TPA}$} & & \\
\cline { 2 - 5 } $\begin{array}{l}\text { Condition } \\
\text { of reaction }\end{array}$ & Yield $^{b}$ & Yield $^{\mathrm{c}}$ & $\mathrm{kBq} / \mathrm{U}$ & $\begin{array}{l}\text { Slope } \\
\text { ratio }\end{array}$ \\
\hline $\mathrm{pH} 7.4$ & 9 & TPA activity & 20 & 1.00 \\
$\mathrm{pH} 7.7$ & 9 & 70 & 15 & 1.00 \\
$\mathrm{pH} 8.5$ & $<1$ & 83 & 2 & 1.00 \\
\hline
\end{tabular}

${ }^{a} \mathrm{pH}$ at the oxidative step. ${ }^{b}$ In $\%$, starting from approx. $40 \mathrm{MBq} .{ }^{c}$ In $\%$, starting from $90 \mathrm{U}$ TPA determined in the hemagglutination test. 
$\mathrm{B}_{1}$ treated in the same way but without the addition of tetranitromethane showed no detectable change of its capacity to inhibit the antibody.

\section{Iodination}

Subfraction $\mathrm{B}_{1}$ was iodinated at high $\mathrm{pH}$ and the results are summarized in Table 4 . The radioactivity and TPA activity of subfraction $B_{1}$, radioiodinated in the presence of chloramine-T, are presented in Table 5. The slope ratio and the minimum diameter in the activity test was the same for the three ${ }^{125} \mathrm{I}$ labeled antigen aliquots as for standard TPA.

\section{Alkylation}

Selective electrophilic alkylation of tryptophan in subfraction $B_{1}$ and $H S A$ gave rise to proteins with extinction coefficients at $410 \mathrm{~nm}(\mathrm{pH} 10.5)^{18}$ for alkylated subfraction $\mathrm{B}_{1}\left(M_{\mathrm{r}} 4.3 \times 10^{4}\right)$ and alkylated HSA $\left(M_{\mathrm{r}} 6.8 \times 10^{4}\right)$ which were found to be $3.4 \times 10^{4}$ and $3.5 \times 10^{4}$, respectively, indicating an equal molecular amount of tryptophan alkylated in each protein (one residue per molecule). The TPA activity was not significantly altered by the alkylation. By amino acid analysis of subfraction $B_{1}$, hydrolyzed with $p$-toluenesulfonic acid in the presence of tryptamine, the mol- $\%$ of tryptophan was found to be 0.3 corresponding to the presence of one residue per molecule of subfraction $B_{1}$. Cyanogen bromide cleavage of subfraction $B_{1}$ and alkylated subfraction $B_{1}$, followed by separation of
Table 6. Modification of arginine residues in subfraction $\mathrm{B}_{1}$ with cyclohexanedione at $\mathrm{pH}$ 9.0.

\begin{tabular}{llll}
\hline $\begin{array}{l}\text { Molar excess } \\
\text { of cyclo- } \\
\text { hexanedione } \\
\text { over available } \\
\text { arginines }\end{array}$ & $\begin{array}{l}\text { Per cent }^{b} \\
\text { decrease } \\
\text { of } \\
\text { arginine }\end{array}$ & $\begin{array}{l}\text { Per cent } \\
\text { decrease } \\
\text { of } \\
\text { activity }\end{array}$ & $\begin{array}{l}\text { Slope } \\
\text { ratio }\end{array}$ \\
\hline $0^{a}$ & 0 & 0 & 1.00 \\
40 & 12 & 17 & 1.00 \\
400 & 54 & 49 & 1.00 \\
4000 & 88 & 97 & 1.00 \\
\hline
\end{tabular}

${ }^{a}$ These values apply to a sample which underwent all reaction steps without the addition of cyclohexanedione and are calculated on basis of untreated TPA subfraction $\mathrm{B}_{1} \cdot{ }^{b}$ By amino acid analysis.

fragments, gave the result presented in Fig. 3 ( $c f$. Ref. 26). The distribution of TPA active fragments is not changed by alkylation whereas the fluorescence of one of the inactive fragments is not detectable after alkylation.

After reaction of subfraction $\mathrm{B}_{1}$ with diazomethane, the activity had decreased to about $50 \%$ but was unchanged in a reference brough through the reaction steps in absence of diazomethane.

\section{Reaction with 1,2-cyclohexanedione}

The degree of modification of arginine residues in subfraction $B_{1}$ after reaction with $1,2-$ cyclohexanedione and its relation to the TPA

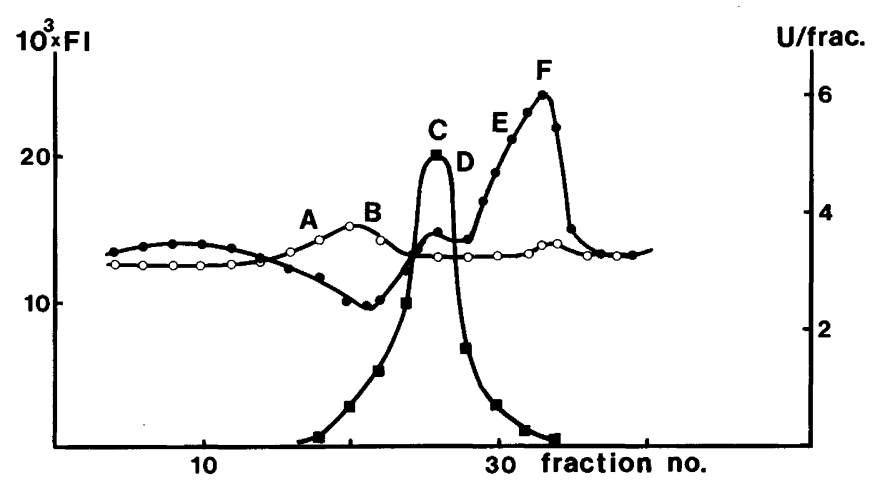

Fig. 3. Gel filtration of $\mathrm{BrCN}$ fragments of subfraction $\mathrm{B}_{1}$ with Sephadex $\mathrm{G} 75$ in $0.1 \mathrm{M}$ formic acid; column: width $1 \mathrm{~cm}$, length $82 \mathrm{~cm}$, fraction volume $1.6 \mathrm{ml}$. $\bigcirc$, fluorescense, activation $288 \mathrm{~nm}$, emission $350 \mathrm{~nm}$ of alkylated subfraction $B_{1}$; , fluorescense, activation $288 \mathrm{~nm}$, emission $350 \mathrm{~nm}$ of non-alkylated subfraction $\mathrm{B}_{1} ; \mathbf{\square}$, TPA-activity of alkylated and non-alkylated subfraction $\mathrm{B}_{1}$ (identical curves). 


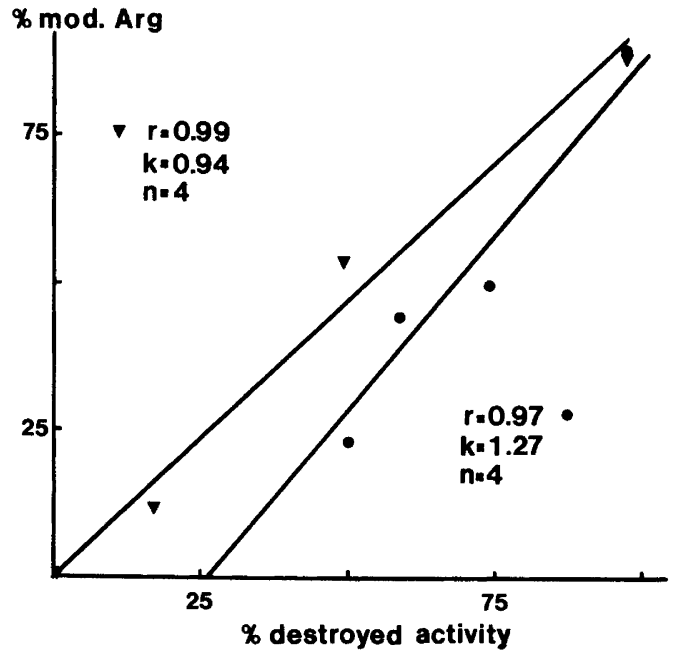

Fig. 4. Relation between $\%$ modified arginine in subfraction $B_{1}$ and perturbation of TPA activity. $\nabla$, blocking of subfraction $\mathrm{B}_{1}$; $\boldsymbol{O}$, de-blocking of DHCH-subfraction $B_{1}$.

activity are presented in Table 6 and Fig. 4. According to amino acid analysis the antigen lost $90 \%$ of detectable arginine and simultaneously the antigen lost $99 \%$ of its capacity to react with the antibodies. An aliquot of subfraction $B_{1}$ which had undergone the same treatment without the addition of reagent, was largely unimpaired.

The reaction product between the guanidinyl groups and cyclohexandione could be cleaved by hydroxylamine and the yield of restored TPA activity and unblocked arginine residues are presented in Table 1 and Fig. 4. There is a linear ratio between TPA activity and degree of blocking of arginine residues in the blocking as well as in the deblocking reaction (Fig. 4). The slope ratio and the minimum diameter in the TPA activity measurements were identical for all reaction products and standard TPA.

Subfraction $B_{1}$, untreated and blocked with cyclohexanedione, was cleaved with trypsine. After cleavage, attempts were made to restore the activity of the fragments by reaction with hydroxylamine. Most of the TPA activity was abolished in the solution of subfraction $\mathbf{B}_{1}$, cleaved without preblocking, whereas $10 \%$ of the TPA activity was restored in the aliquot that had been blocked with DHCH groups during cleavage (Table 7). The two aliquots were filtered through Sephadex G 50 fine (Figs. 5a and 5b, Table 7). The TPA activity of low $M_{r}$ fragments was measured after concentration of the solutions.

\section{Circulardichroism measurements}

CD was measured for solutions of widely distributed $\mathrm{pH}$ values and at different concentrations. The ellipticities are collected in Table 8 and Fig. 6. The data are expressed in mean residue ellipticities, taking 115 for the mean residue weight of subfraction $B_{1}$. The appearance of a strong positive band at $192 \mathrm{~nm}$ and negative bands at 208 and $222 \mathrm{~nm}$ (Figs. $6 \mathrm{a}$ and $6 \mathrm{~b}$ ) indicate the presence of a great deal of $\alpha$-helix. ${ }^{27,28}$ Estimates indicate an

Table 7. TPA activity of tryptic fragments of subfraction $B_{1}$ and DHCH-subfraction $B_{1}$.

\begin{tabular}{|c|c|c|c|}
\hline Treated material $^{a}$ & $\begin{array}{l}\text { Yield } \\
\text { TPA activity }\end{array}$ & $\begin{array}{l}\text { Slope }^{c} \\
\text { ratio }\end{array}$ & $M_{\mathrm{r}}^{d}$ \\
\hline $\begin{array}{l}\text { Subfraction } B_{1} \\
\text { T } \\
\text { T,S(P I a) } \\
\text { T,S(P I b) }\end{array}$ & $\begin{array}{r}100.0 \\
<0.4 \\
0.1 \\
<0.1\end{array}$ & $\begin{array}{l}1.00 \mathrm{C} \\
\overline{1.00 \mathrm{C}} \\
0.78-\end{array}$ & $\begin{array}{l}- \\
\overline{2}-5 \times 10^{3} \\
2 \times 10^{3}\end{array}$ \\
\hline $\begin{array}{l}\text { DHCH-subfraction } \mathrm{B}_{1} \\
\text { D } \\
\text { D,T } \\
\text { D,T,S(P II a) } \\
\text { D,T,S(P II b) }\end{array}$ & $\begin{array}{r}0 \\
50.0 \\
10.0 \\
0.7 \\
1.0\end{array}$ & $\begin{array}{l}\overline{-} \overline{-} \\
0.93 \mathrm{C} \\
1.02 \mathrm{C} \\
0.67 \mathrm{I} \\
0.56 \mathrm{I}\end{array}$ & $\begin{array}{l}- \\
\overline{-} \\
\overline{10-12 \times 10^{3}} \\
6-8 \times 10^{3}\end{array}$ \\
\hline
\end{tabular}

${ }^{a} \mathrm{~T}=$ trypsine cleaved; $\mathrm{D}=$ de-blocked; $\mathrm{P}=$ pooled and concentrated (see Fig. 5 ); $\mathrm{S}=$ material filtered with Sephadex $\mathrm{G}$ 50 fine. ${ }^{b} \%$ based on starting material. ${ }^{c} \mathrm{C}=$ complete inhibition; $\mathrm{I}=$ incomplete inhibition. ${ }^{d}$ Approx. determination by gelfiltration. 

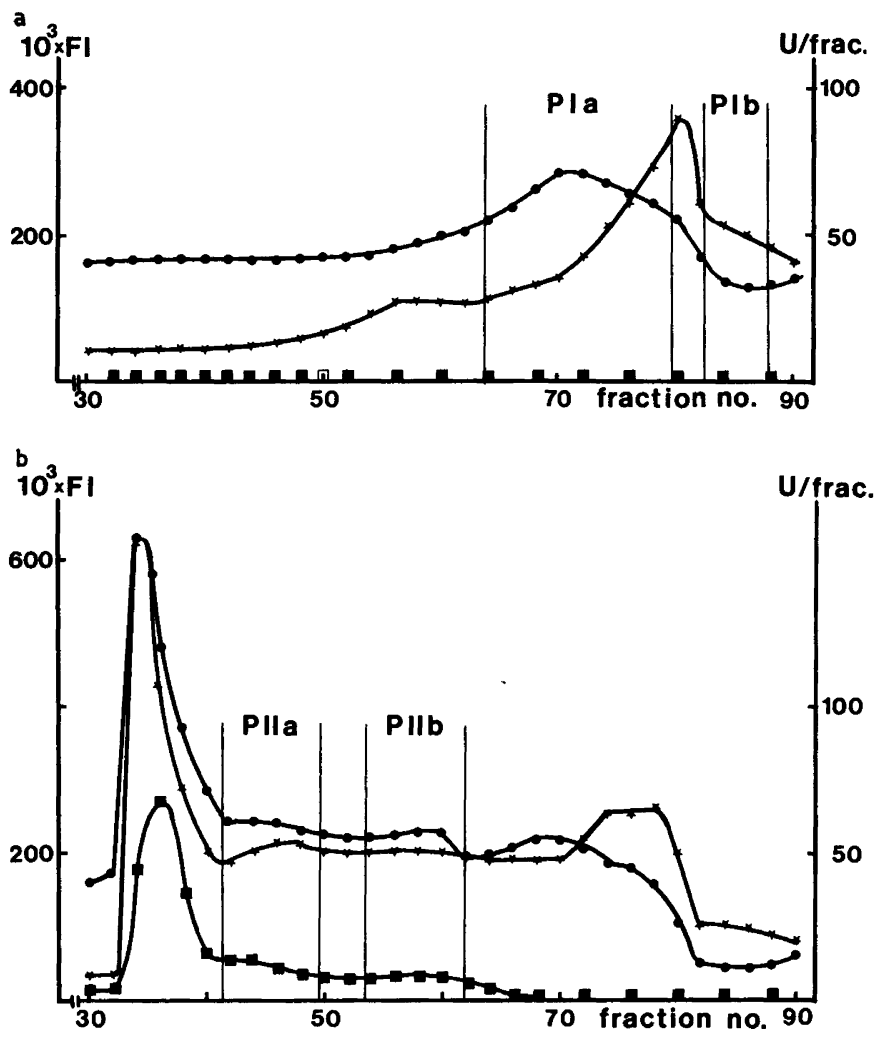

Fig. 5. Gel filtration of trypsine-cleaved subfraction $B_{1}(a)$ and DHCH-subfraction $B_{1}$ (b), with Sephadex $G 50$ fine in $0.2 \mathrm{M} \mathrm{NH}_{4} \mathrm{HCO}_{3}$ at $5 \mathrm{C}$; column: width $2.5 \mathrm{~cm}$, length $140 \mathrm{~cm}$, fraction volume $8.5 \mathrm{ml}$. $\star$ fluorescence, activation $288 \mathrm{~nm}$, emission $350 \mathrm{~nm}$; , fluorescence, activation $288 \mathrm{~nm}$, emission $312 \mathrm{~nm}$; , TPA activity.

amount of around $80 \% \alpha$-helix at $\mathrm{pH} 2$ and 12 in subfraction $B_{1}$ whereas only $60 \% \alpha$-helix is present at $\mathrm{pH}$ 8.4. Succinylation is accompanied by a rise in $\alpha$-helix to $70 \%$ whereas the stabilization of $\alpha$-helix is disturbed in the presence of SDS and in the DHCHderivative. The high value of $\alpha$-helix is well in agreement with calculations for secondary structure ${ }^{29,30}$ made on hitherto sequenced parts of

Table 8. Molar residue ellipticities and $\alpha$-helical content of TPA preparations.

\begin{tabular}{|c|c|c|c|c|c|c|}
\hline TPA preparation & Dissolved in ${ }^{a}$ & $\begin{array}{l}\text { Conc. } \\
(\mu \mathrm{g} / \mathrm{ml})\end{array}$ & $\begin{array}{l}10^{-3} \times \theta \\
(208 \mathrm{~nm})^{b}\end{array}$ & $\begin{array}{l}10^{-3} \times \theta \\
(217 \mathrm{~nm})^{b}\end{array}$ & $\begin{array}{l}10^{-3} \times \theta \\
(222 \mathrm{~nm})^{b}\end{array}$ & $\begin{array}{l}\% \\
\alpha \text {-helix }\end{array}$ \\
\hline Subfraction $B_{1}$ & $0.01 \mathrm{M} \mathrm{HCl}$ & 24 & 29.5 & 27.8 & 30.1 & 88 \\
\hline Subfraction $\mathbf{B}_{1}$ & $0.01 \mathrm{M} \mathrm{HCl}$ & 953 & 30.2 & 29.1 & 30.6 & 90 \\
\hline Subfraction $\mathrm{B}_{1}$ & $0.01 \mathrm{M} \mathrm{NaOH}$ & 28 & 24.5 & 22.2 & 24.5 & 71 \\
\hline Subfraction $\mathbf{B}_{1}$ & $0.01 \mathrm{M} \mathrm{NaOH}$ & 1100 & 27.0 & 26.1 & 27.7 & 79 \\
\hline SDS treated & $0.1 \mathrm{M} \mathrm{NaHCO}{ }_{3} 1 \%$ SDS & 31 & 15.8 & 11.8 & 13.0 & 41 \\
\hline Subfraction $B_{1}$ & $0.1 \mathrm{M} \mathrm{NaHCO}_{3} 1 \%$ SDS & 1235 & 16.9 & 13.8 & 14.1 & 45 \\
\hline Subfraction $\mathbf{B}_{1}$ & $0.1 \mathrm{M} \mathrm{NaHCO}_{3}$ & 28 & 20.7 & 18.0 & 19.9 & 58 \\
\hline Succinyl-subfr. $B_{1}$ & $0.1 \mathrm{M} \mathrm{NaHCO}_{3}$ & 34 & 25.5 & 22.5 & 24.0 & 74 \\
\hline DHCH-subfraction $\mathrm{B}_{1}$ & $0.1 \mathrm{M} \mathrm{NaHCO}_{3}$ & 36 & 14.7 & 12.6 & 13.8 & 37 \\
\hline
\end{tabular}

${ }^{a}$ Glass distilled water used. ${ }^{b} \mathrm{deg} . \mathrm{cm}^{2} / \mathrm{d} \mathrm{mol}$. 

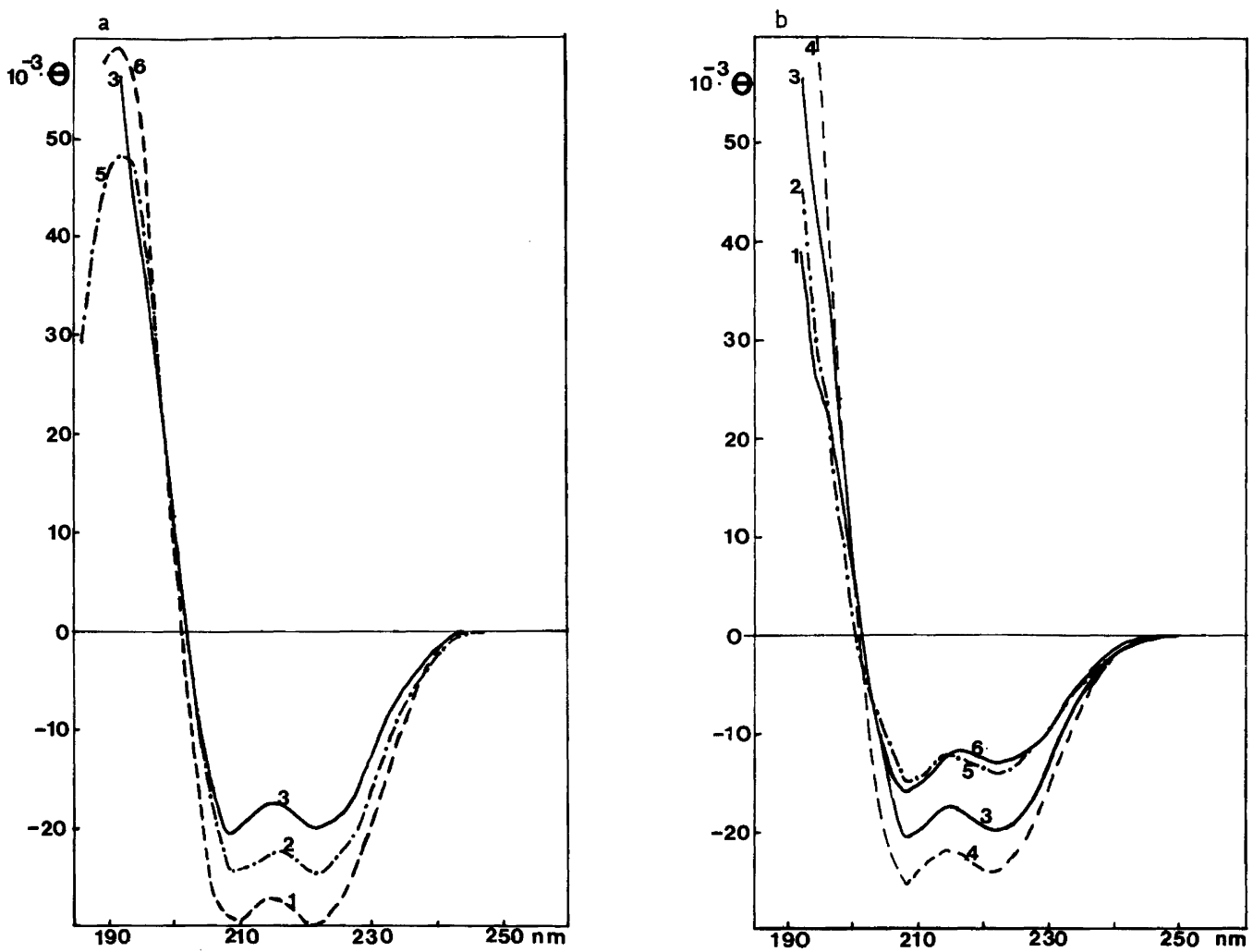

Fig. 6. Circular dichroism curves of TPA preparations: 1 , Subfraction $\mathrm{B}_{1}, 24 \mu \mathrm{g} / \mathrm{ml}$ in $0.01 \mathrm{M} \mathrm{HCl} 22$, Subfraction $\mathrm{B}_{1}, 28 \mu \mathrm{g} / \mathrm{ml}$ in $0.01 \mathrm{M} \mathrm{NaOH} ; 3$, Subfraction $\mathrm{B}_{1}, 28 \mu \mathrm{g} / \mathrm{ml}$ in $0.1 \mathrm{M} \mathrm{NaHCO} ; 4$, Succinylated subfraction $\mathrm{B}_{1}, 34 \mu \mathrm{g} / \mathrm{ml}$ in $0.1 \mathrm{M} \mathrm{NaHCO}_{3} ; 5$, DHCH-subfraction $\mathrm{B}_{1}, 36 \mu \mathrm{g} / \mathrm{ml}$ in $0.1 \mathrm{M} \mathrm{NaHCO}_{3} ; 6$, $\mathrm{SDS}$ subfraction $\mathrm{B}_{1}, 31 \mu \mathrm{g} / \mathrm{ml}$ in $0.1 \mathrm{M} \mathrm{NaHCO}_{3}, 1 \% \mathrm{SDS}$.

TPA $^{26}$ (150 amino acid residues) which indicate the presence of $70-80 \% \alpha$-helix, only minor amounts of $\beta$-pleated sheet and $1-2 \beta$-turns. This result is not surprising in view of the high molecular percentage of Glu (17.9), Ala (8.6) and Leu (10.8) in subfraction $B_{1}$. There is no clearcut correlation between secondary structure and TPA activity.

\section{DISCUSSION}

TPA subfraction $B_{1}$ has been found to give rise to antibodies in rabbit which produce a line of identity in gel diffusion between TPA subfractions $B_{1}, B_{2}$ and C. The rabbit anti TPA: $B_{1}$ serum gives only one weak line against normal human serum, thereby confirming the immunological purity of the antigen. The subfractions are also indistinguishable by hemagglutination inhibition. Since no differences were found between subfractions $B_{1}, B_{2}$ and $C$ and $\mathrm{B}_{1}$ is the major reasonably pure product, the latter was chosen for most subsequent work on the chemistry of TPA. The rabbit anti TPA:B ${ }_{1}$ serum also has the the ability to detect TPA active structures by immunohistology in cancer cells of various locations ${ }^{31}$ as well as in a few other cell types. ${ }^{32}$ Therefore the purification procedure would not markedly change the immunological specificity of the protein. A precipitin line of identity (Fig. 1) is also found between products from various steps of preparation, including heat treatment. The finding that the protein is largely $\alpha$-helical also indicates that the protein is not heavily denaturated. The elongated $\alpha$-helical structure of TPA: $\mathrm{B}_{1}{ }^{1}$ implies that all groups should be equally accessible for 
chemical reactions. This is observed in the blocking of arginine with cyclohexanedione and de-blocking with hydroxylamine, where a linear relationship is obtained between TPA activity and free arginine. The complete inactivation and reactivation attainable, show that all antibody binding sites in TPA:B $B_{1}$ are dependent, directly or indirectly, of arginine for their function. The excess of cyclohexanedione required for reaction with TPA: $B_{1}$, illustrated by a logarithmic relationship between the concentration of reagent and the extent of modification, can be explained in terms of an equilibrium between sterically hindered aggregates and oligomeric TPA:B $B_{1}$ A hundredfold higher molar excess of reagent has to be used to obtain quantitative modification with TPA: $\mathbf{B}_{1}$ than with other proteins. ${ }^{7}$ The occurrence of polymeric states of TPA:B $B_{1}$ can also be inferred from the results of sedimentation analysis. ${ }^{1}$

Acylation of lysine residues does not markedly change the activity of TPA: $B_{1}$ and the activity is also retained when de-acylating citraconylated TPA: $B_{1}$. Dansylation of TPA: $B_{1}$ completely removes its activity. This may be due to steric effects of the bulky dansyl group or to sulfonation of tyrosine, the dansyl ester of which constitutes a prominent spot in TLC after $\mathrm{HCl}$ hydrolysis. No $\mathrm{N}$-terminal amino acid was, however, revealed by this method. The role of tyrosine for the activity is not clear since exhaustive nitration only slightly removed the activity.

Toluenesulfonic acid hydrolysis of TPA: $\mathrm{B}_{1}$ in the presence of tryptamine showed the presence of one tryptophan residue per TPA: $\mathrm{B}_{1}$ molecule and Trp was also found to be responsible for the characteristic fluorescence of TPA: $B_{1}$. Alkylation of the indole nucleus of Trp did not markedly decrease the activity of TPA: $B_{1}$ and subsequent cleavage of the alkylated product, compared with the corresponding cleavage of intact TPA: $\mathrm{B}_{1}$, showed that a prominent active site in TPA: $B_{1}$ is located in a fragment differing from that containing Trp. For a globular protein, having an $M_{\mathrm{r}}$ of around 43000 , one can expect the occurrence of five immunoreactive sites. ${ }^{33}$ In TPA: $B_{1}$, which has a fibrous character, three sites have so far been found, ${ }^{26}$ one in the sequenced part of $\mathrm{BrCN}$ fragment $B$ and one in the peptide remaining after sequencing of the same fragment. The third active site is located in $\mathrm{BrCN}$ fragment $\mathrm{C}$ between amino acids 20 and 50 in a strictly $\alpha$-helical region (calculated). ${ }^{29,30}$ Fragment peptides with partial
TPA activity, showing up as a diminished slope ratio in the hemaglutination assay, are obtained by $\mathrm{BrCN}$ cleavage as well as in trypsine cleavage of TPA:B previously reacted with cyclohexanedione. In the latter case the fragment peptides show their activity only after de-blocking with hydroxylamine.

Acknowledgements. This work was supported by the Swedish Government, the Bonnier Company Inc., and the Folksam Insurance Company. We thank Professor Salo Gronowitz for putting a cicular dichroism instrument at our disposal, and Mr. Jan Glans and Rolf Håkansson for aid in measuring the ellipticity of TPA-preparations.

\section{REFERENCES}

1. Lüning, B., Wiklund, B., Redelius, P. and Björklund, B. Biochim. Biophys. Acta 624 (1980) 90.

2. Westwood, J., Thomas, P., Edwards, B., Scopes, P. and Barret, M. Br. J. Cancer 37 (1978) 183.

3. Björklund, B., Björklund, V., Wiklund, B., Lundström, R., Ekdahl, P., Hagbard, L., Kaijser, K., Eklund, G. and Lüning, B. Immunological Techniques for Detection of Cancer, Bonniers, Stockholm 1973, pp. 134, 237.

4. Björklund, B. Anal. Biochem. 41 (1971) 287.

5. Björklund, B. Int. Arch. Allergy Appl. Immunol. 36 (1969) 191.

6. Björklund, B. In Schönfeld, H., Ed., Antibiotics and Chemotherapy, Karger, Basel 1978, Vol. 22, p. 16.

7. Patthy, L. and Smith, E. J. Biol. Chem. 250 (1975) 557.

8. Liu, T. and Chang, Y. J. Biol. Chem. 246 (1971) 2842.

9. Habeeb, A., Cassidy, H. and Singer, S. Biochim. Biophys. Acta 29 (1958) 587.

10. Butler, P., Harris, J., Hartley, B. and Leberman, R. Biochem. J. 112 (1969) 679.

11. Dixon, H. and Perham, R. Biochem. J. 109 (1968) 312.

12. Hartley, B. and Massey, V. Biochim. Biophys. Acta 21 (1956) 58.

13. Bolton, A. and Hunter, W. Biochem. J. 133 (1973) 529.

14. Sokolovsky, M., Riordan, J. amd Vallee, B. Biochemistry 5 (1966) 3582.

15. Atassi, M. In Atassi, M., Ed., Immunochemistry of Proteins, Plenum, New York 1977, Vol. 1, p. 1.

16. Cha, C. and Scheraga, H. J. Biol. Chem. 238 (1963) 2958.

17. Greenwood, F., Hunter, W. and Glover, J. Biochem. J. 89 (1963) 114. 
18. Horton, H. and Tucker, W. J. Biol. Chem. 245 (1970) 3397.

19. Steers, E., Jr., Craven, G., Anfinsen, C. and Bethune, J. J. Biol. Chem. 240 (1965) 2478.

20. Chibnall, A., Mangan, J. and Rees, N. Biochem. J. 68 (1958) 114.

21. Toi, K., Bynum, E., Norris, E. and Itano, H. J. Biol. Chem. 242 (1967) 1036.

22. Habeeb, A. and Atassi, M. Immunochemistry 8 (1971) 1047.

23. Hartley, B. Biochem. J. 119 (1970) 805.

24. Wiklund, B., Kallin, E., Andersson, K. and Björklund, B. In Peeters, H., Ed., Protides Biol. Fluids Proc. Colloq., Pergamon, Oxford 1979, Vol. 27, p. 243.

25. Björklund, B., Wiklund, B., Lüning, B., Andersson, K., Kallin, E. and Björklund, V. Tumordiagnostik 1 (1980) 78.

26. Redelius, P., Lüning, B. and Björklund, B. Acta Chem. Scand. B 34 (1980) 265.

27. Greenfield, N. and Fasman, G. Biochemistry 8 (1969) 4108.

28. Jirgensons, B. Optical Activity of Proteins and Other Macromolecules, Springer, Berlin 1973, p. 126.

29. Levitt, M. Biochemistry 17 (1978) 4277.

30. Chou, P. and Fasman, G. Adv. Enzymol. Relat. Subj. Biochem. 47 (1978) 45.

31. Björklund, V. and Björklund, B. In Peeters, H., Ed., Protides Biol. Fluids Proc. Colloq., Pergamon, Oxford 1979, Vol. 27, p. 229.

32. Björklund, B. Tumordiagnostik 1 (1980) 9.

33. Kabat, E. J. Immunol. 97 (1966) 1.

Received January 7, 1981. 